\title{
Activation of bitter taste receptors (tas2rs) relaxes detrusor smooth muscle and suppresses overactive bladder symptoms
}

\author{
Kui Zhai ${ }^{1, *}$, Zhiguang Yang ${ }^{1, *}$, Xiaofei Zhu ${ }^{2,}{ }^{*}$, Eric Nyirimigabo ${ }^{1}$, Yue Mi $^{3}$, Yan Wang ${ }^{4}$, \\ Qinghua Liu ${ }^{5}$, Libo Man ${ }^{2}$, Shiliang $\mathrm{Wu}^{3}$, Jie Jin ${ }^{3}$ and Guangju $\mathrm{Ji}^{1}$ \\ ${ }^{1}$ National Laboratory of Biomacromolecules, Institute of Biophysics, Chinese Academy of Sciences, Beijing, China \\ 2 Department of Urology, Beijing Jishuitan Hospital, Beijing, China \\ ${ }^{3}$ Department of Urology, National Research Center for Genitourinary Oncology, Peking University First Hospital and Institute \\ of Urology, Beijing, China \\ ${ }^{4}$ Department of Gastroenterology, Peking University First Hospital, Beijing, China \\ ${ }^{5}$ Institute for Medical Biology, College of Life Sciences, South-Central University for Nationalities, Wuhan, China \\ * Those authors have contributed equally to this work \\ Correspondence to: Guangju Ji, email: gj28@ibp.ac.cn \\ Jie Jin, email: jinjie@vip. 163.com
}

Keywords: bitter taste receptors, chloroquine, detrusor smooth muscle, human, mouse, overactive bladder, Gerotarget

Received: March 10, 2016

Accepted: March 20, 2016

Published: April 02, 2016

\section{ABSTRACT}

Bitter taste receptors (TAS2Rs) are traditionally thought to be expressed exclusively on the taste buds of the tongue. However, accumulating evidence has indicated that this receptor family performs non-gustatory functions outside the mouth in addition to taste. Here, we examined the role of TAS2Rs in human and mouse detrusor smooth muscle (DSM). We showed that mRNA for various TAS2R subtypes was expressed in both human and mouse detrusor smooth muscle (DSM) at distinct levels. Chloroquine (CLQ), an agonist for TAS2Rs, concentration-dependently relaxed carbachol- and $\mathrm{KCl}$-induced contractions of human DSM strips. Moreover, $100 \mu \mathrm{M}$ of CLQ significantly inhibited spontaneous and electrical field stimulation (EFS)-induced contractions of human DSM strips. After a slight contraction, CLQ (1 mM) entirely relaxed carbachol-induced contraction of mouse DSM strips. Furthermore, denatonium and quinine concentration-dependently decreased carbachol-induced contractions of mouse DSM strips. Finally, we demonstrated that CLQ treatment significantly suppressed the overactive bladder (OAB) symptoms of mice with partial bladder outlet obstruction (PBOO). In conclusion, we for the first time provide evidence of the existence of TAS2Rs in the urinary DSM and demonstrate that TAS2Rs may represent a potential target for $O A B$. These findings open a new approach to develop drugs for $O A B$ in the future.

\section{INTRODUCTION}

The urinary bladder is the organ that collects urine excreted from kidneys before disposal by urination. Bladder dysfunction, such as overactive bladder (OAB), has serious effects on quality of life [1]. OAB syndrome is a common condition characterized by the presence of urgency with or without incontinence, frequency, and nocturia. The etiology of OAB syndrome is very complicated and includes increased afferent activity, decreased inhibitory control, and increased sensitivity of the detrusor muscle to efferent stimulation [2]. It has been reported that the overall prevalence of $\mathrm{OAB}$ syndrome was $11.8 \%$; rates were similar between men and women [3]. The prevalence of $\mathrm{OAB}$ syndrome increased with age in a linear fashion [3-5]. As a result, in patients over the age of 65 years the prevalence of OAB syndrome can increase to $30.9 \%$ [4]. Anticholinergic drugs remain the first-line pharmacologic treatment for OAB syndrome [6] despite producing undesirable side effects such as dry mouth, constipation, and blurred vision [7]. It is estimated that by 2018 , more than 500 million people worldwide will be affected by OAB $[3,8]$. Thus, it is of great urgency to identify novel targets for this disorder. 
Bitter taste receptors (TAS2Rs) belong to the superfamily of G-protein-coupled receptors (GPCRs) [9]. GPCRs, which convert extracellular stimuli into intracellular signals through the activation of heterotrimeric G-proteins, are involved in many diseases and are also the target of approximately $40 \%$ of all modern medicinal drugs [10]. However, these targeted GPCRs are only a small part of this receptor superfamily and over 30\% GPCRs have no known endogenous ligand, indicating that many potential targets remain to be discovered [11]. As TAS2Rs are traditionally thought to be expressed exclusively on the taste buds of the tongue, they have been generally neglected as drug targets. However, accumulating evidence has indicated that this receptor family performs non-gustatory functions outside the mouth in addition to taste. We and others have shown that TAS2Rs are expressed in both human and mouse airway smooth muscle and mediate the tone of airway smooth muscle [12-15]. Besides, it has been reported that this receptor family plays a critical role in the heart [16], thyroid [17], and gastrointestinal muscle [18]. However, their role in the urinary bladder has never been determined.

In this study, we examined the expression and function of TAS2Rs in human and mouse urinary detrusor smooth muscle (DSM). We further determined their role in the urinary bladder of mice with partial bladder outlet obstruction (PBOO).

\section{RESULTS}

\section{Expression profile of Tas2rs in human DSM}

Using quantitative reverse transcription PCR (RTqPCR), we screened the expression profile of all 25 $T A S 2 R$ genes in human DSM. As shown in Figure 1, we found that $T A S 2 R 7$ and $T A S 2 R 8$ were the most abundantly expressed genes, with levels similar to the reference gene glyceraldehyde 3-phosphate dehydrogenase $(G A P D H)$. The expression levels of TAS2R1, TAS2R5, $T A S 2 R 9$, TAS2R13, TAS2R20, and TAS2R31 were two orders of magnitude lower than that of $G A P D H$ with the following rank order: TAS $2 R 13>T A S 2 R 1 \approx T A S 2 R 9$

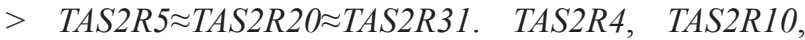
TAS2R14, TAS2R30, TAS2R38,TAS2R39, TAS2R40, $T A S 2 R 45$, and $T A S 2 R 50$ were very slightly detected. Eight $T A S 2 R$ genes (TAS2R3, TAS2R16, TAS2R19, TAS2R41, $T A S 2 R 42, T A S 2 R 43, T A S 2 R 46$, and TAS2R60) were not expressed.

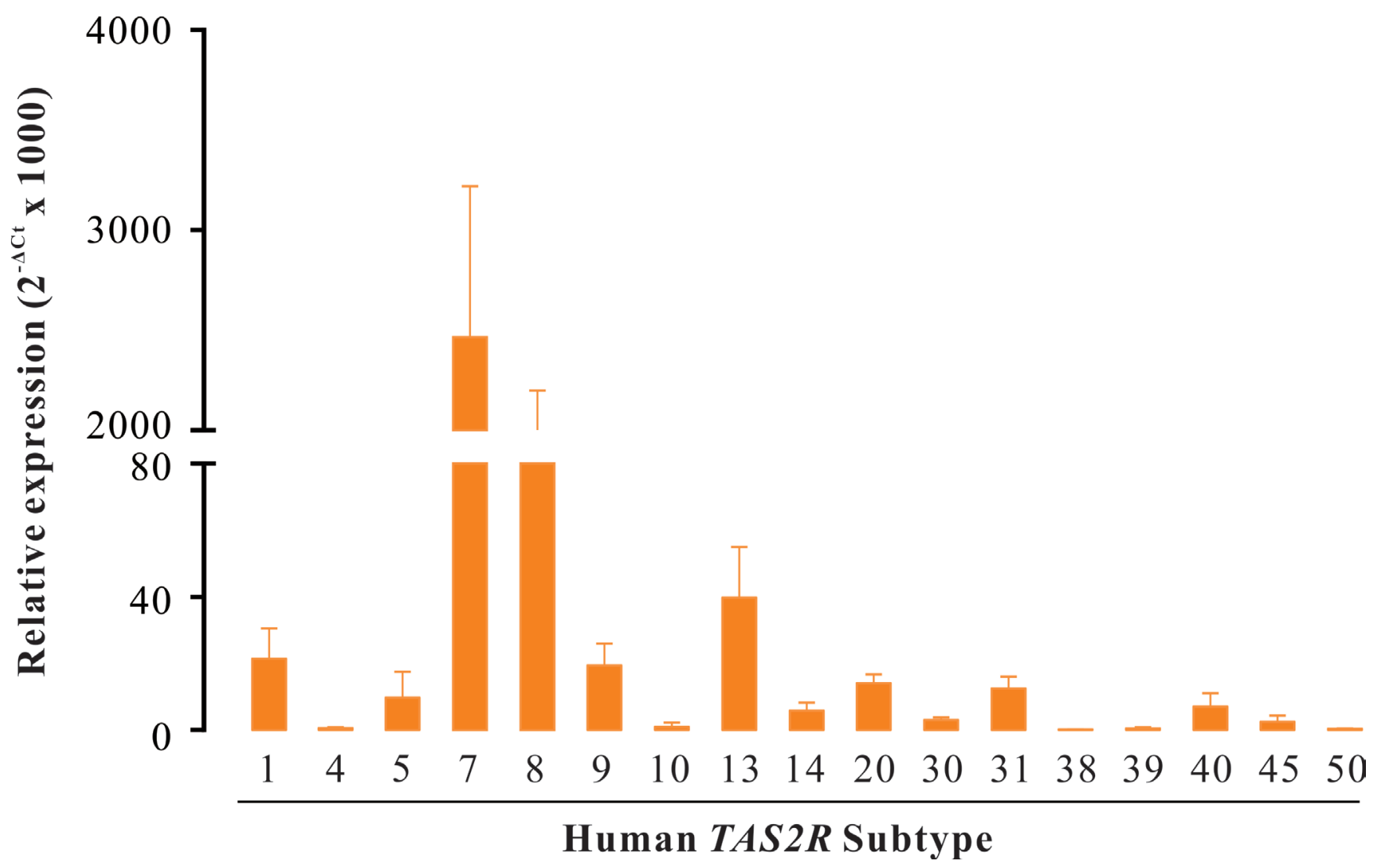

Figure 1: The genes of $\boldsymbol{T A S} 2 \boldsymbol{R}$ are expressed in human DSM. RT-qPCR screen of $T A S 2 R$ genes in human DSM. Data were presented as relative expression of TAS $2 R$ genes to the reference gene GAPDH (mean \pm SEM of 5 independent DSM samples). Of all 25 human TAS2R gens, $17 T A S 2 R s$ were expressed in human DSM with distinct levels, whereas $8 T A S 2 R$ s were not detected. 


\section{Chloroquine (CLQ) relaxes human DSM strips}

Next, we determined the function of TAS2Rs in human DSM with chloroquine (CLQ). CLQ is an agonist of TAS2Rs and has been shown to activate several TAS2Rs, including TAS2R3, TAS2R7, TAS2R10, and TAS2R39 [19-21]. We showed that CLQ did not exhibit any effects on the base tone of human DSM strips. We thus tested the effect of CLQ on carbachol- and KClinduced contractions of human DSM strips according to previous studies [22-24]. We showed that cumulative concentrations of CLQ (100 nM to $3 \mathrm{mM})$ induced significant decreases of carbachol- and $\mathrm{KCl}$-induced contractions in a concentration-dependent manner (Figure 2A-2D). In contrast, the vehicle had no significant effects

$\mathbf{A}$
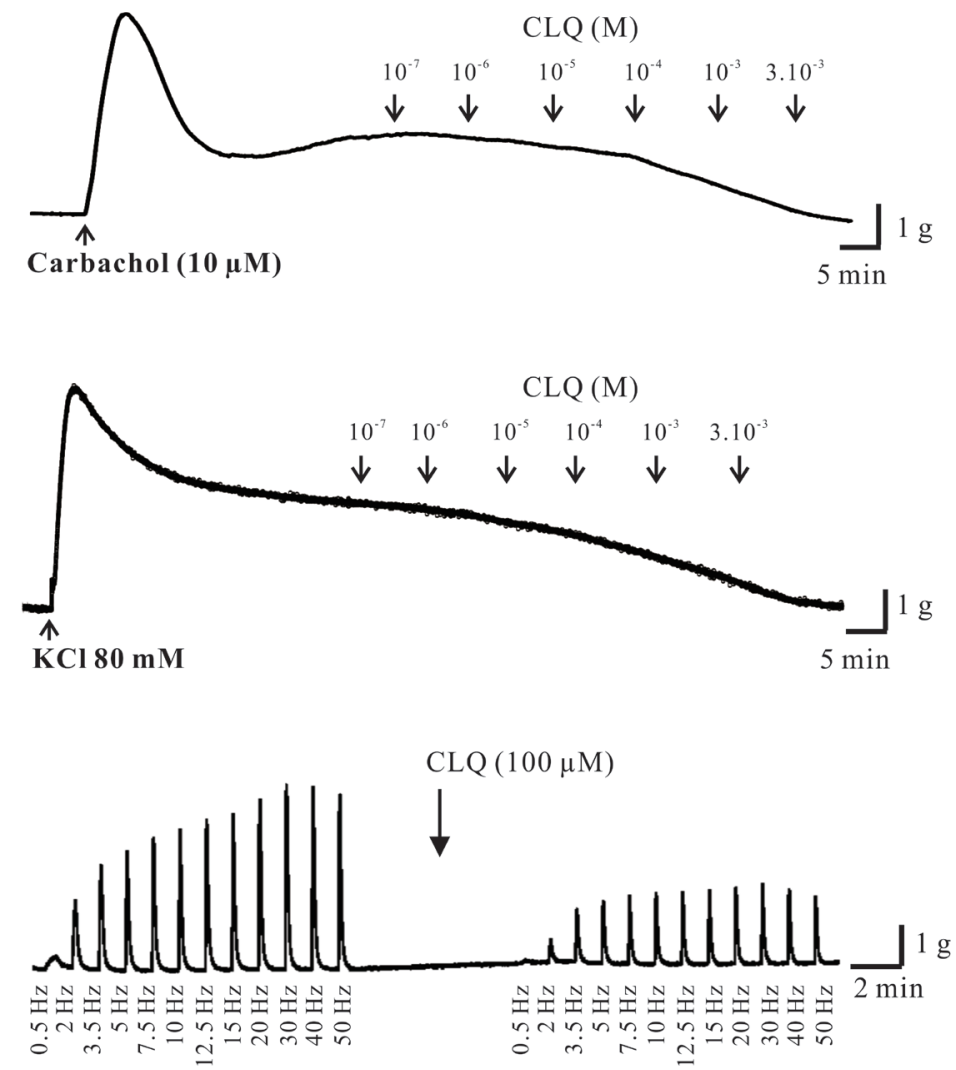

G

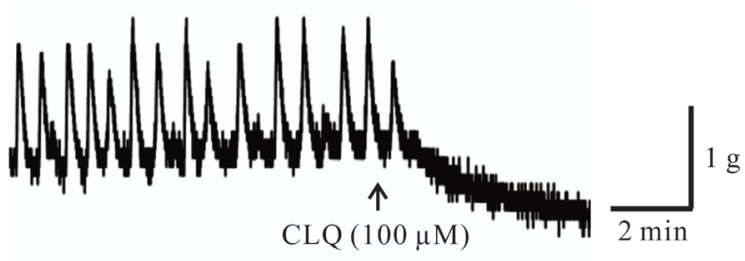

C

$\mathbf{E}$

Carbachol $(10 \mu \mathrm{M})$

KCI $80 \mathrm{mM}$

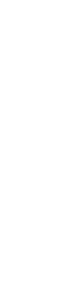

on these contractions (Figure 2B and 2D). Moreover, we investigated the effects of CLQ on the nerve-evoked contractions induced by a wide range of electrical field stimulation (EFS) frequencies as described from Petkov's work [25]. We first applied increasing EFS frequencies $(0.5-50 \mathrm{~Hz})$ as a control protocol, followed by the addition of $100 \mu \mathrm{M}$ CLQ (Figure 3E). Five minutes after the addition, a second EFS protocol was applied. As shown in Figure 3F, CLQ $(100 \mu \mathrm{M})$ significantly decreased the amplitudes of EFS-induced contractions within a wide range $(0.5 \mathrm{~Hz}, 2 \mathrm{~Hz}, 3.5 \mathrm{~Hz}, 5 \mathrm{~Hz}, 7.5 \mathrm{~Hz}, 10 \mathrm{~Hz}, 12.5$ $\mathrm{Hz}, 15 \mathrm{~Hz}, 20 \mathrm{~Hz}, 30 \mathrm{~Hz}, 40 \mathrm{~Hz}$, and $50 \mathrm{~Hz})$ by $21 \pm$ $12 \%, 52 \pm 15 \%, 26 \pm 14 \%, 32 \pm 10 \%, 31 \pm 10 \%, 40 \pm$ $5 \%, 50 \pm 8 \%, 558 \%, 46 \pm 10 \%, 48 \pm 13 \%$, and $57 \pm 19 \%$, respectively. Of all the strips ( $n=26)$, only three exhibited
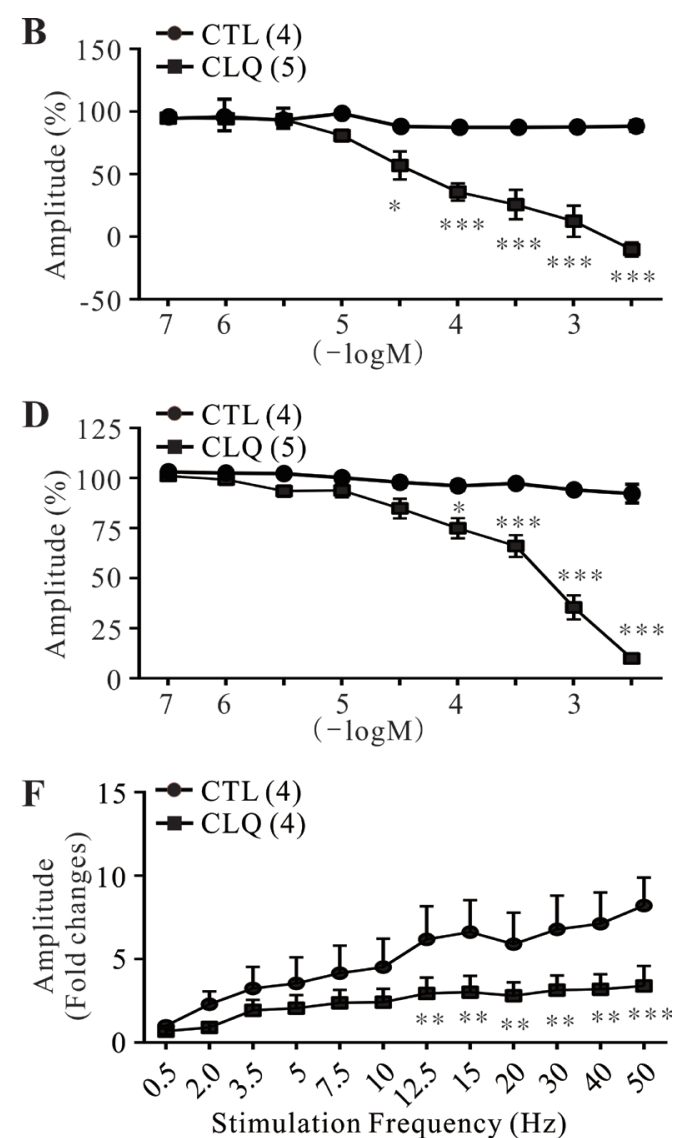

Stimulation Frequency $(\mathrm{Hz})$

Figure 2: Effect of chloroquine on stimulus-induced and spontaneous contractions of human DSM strips. A., B. Original trace and summary data showing the effects of vehicle (control, $n=4$ strips) or chloroquine (CLQ: $100 \mathrm{nM}$ to $3 \mathrm{mM} ; n=5$ strips) on carbachol-induced contractions. C., D. Original trace and summary data showing the effects of vehicle (control, $n=4$ strips) or CLQ (100 $\mathrm{nM}$ to $3 \mathrm{mM} ; n=5$ strips) on KCl-induced contractions. E., F. Original trace and summary data showing the effects of CLQ (100 $\mu \mathrm{M})$ on EFS-induced contractions ( $n=4$ strips). G. Original trace of spontaneous contractions in the absence and presence of $100 \mu \mathrm{M}$ CLQ. Data are mean \pm SEM of $\mathrm{n}$ independent DSM strips. ${ }^{*} p<0.05,{ }^{* *} p<0.01$, and ${ }^{* * *} p<0.001$ as indicated. 


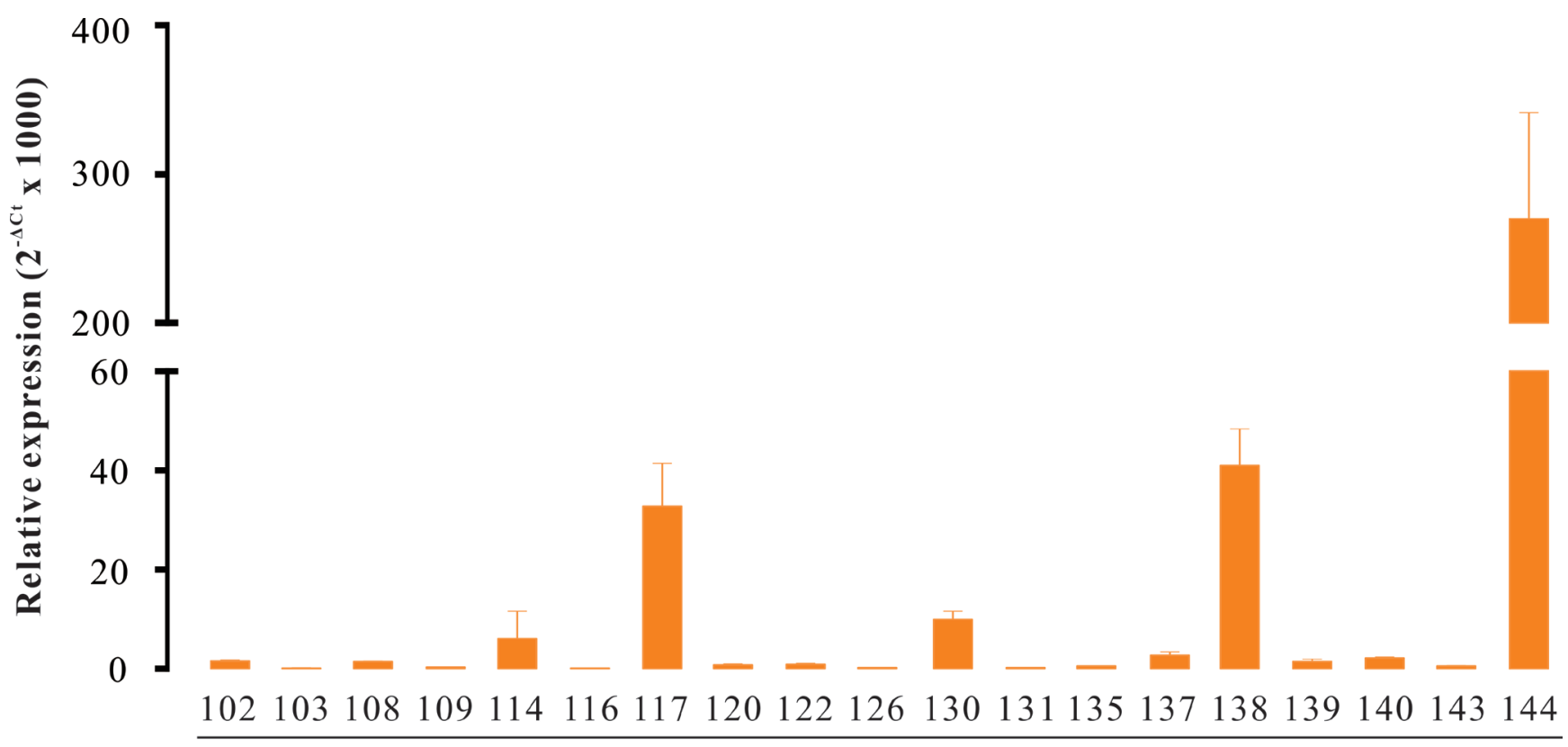

\section{Mouse Tas2r Subtype}

Figure 3: The genes of Tas2 $r$ are expressed in mouse DSM. RT-qPCR screen of Tas2 $r$ genes in mouse DSM. Data were presented as relative expression of Tas $2 r$ genes to the reference gene Gapdh (mean \pm SEM of 3 independent DSM samples). Of all 35 mouse Tas $2 r$ genes, 19 Tas2rs were expressed in mouse DSM with distinct levels, whereas 16 Tas $2 r$ s were not detected.

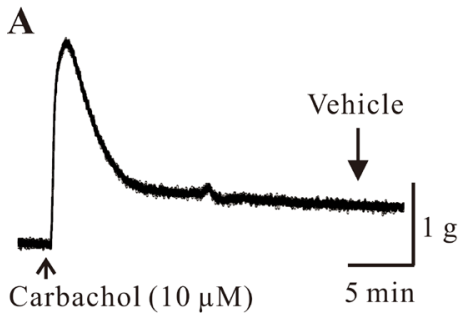

D

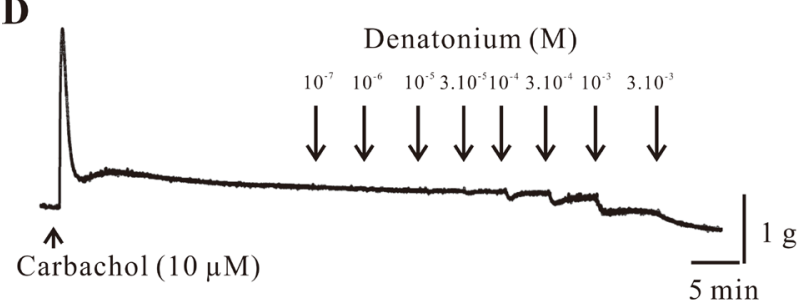

E

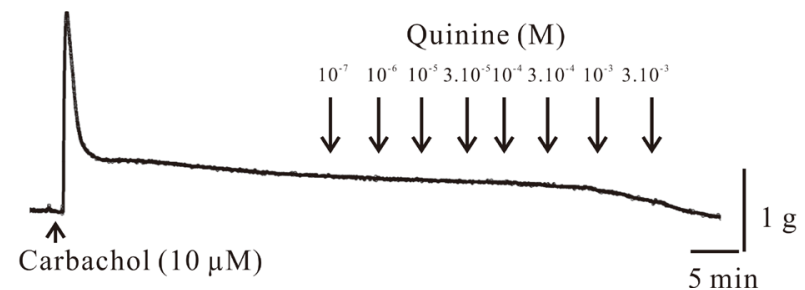

B

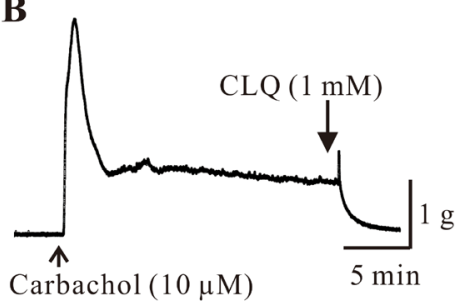

C

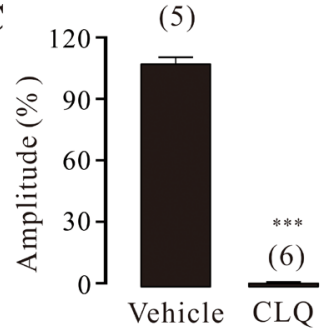

$\mathbf{F}$

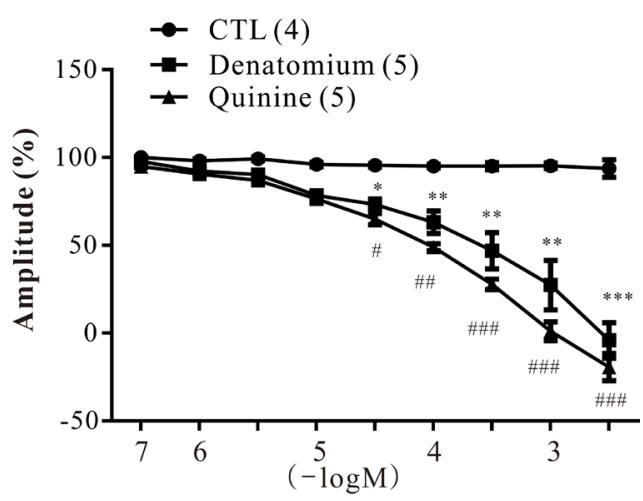

Figure 4: Effect of bitter tastants on carbachol-induced contractions of mouse DSM strips. A.-C. Original traces and summary data showing the effects of vehicle (control, $n=5$ strips) or chloroquine (CLQ: $1 \mathrm{mM} ; n=6$ strips) on carbachol-induced contractions in mouse DSM strips. D. Original trace showing the effects of denatonium ( $100 \mathrm{nM}$ to $3 \mathrm{mM})$ on carbachol-induced contractions. E. Original trace showing the effects of quinine ( $100 \mathrm{nM}$ to $3 \mathrm{mM})$ on carbachol-induced contractions. F. Summary data showing the effects of vehicle, denatonium ( $n=5$ strips), and quinine ( $n=5$ strips) on carbachol-induced contractions. Data are mean \pm SEM of $\mathrm{n}$ independent mouse

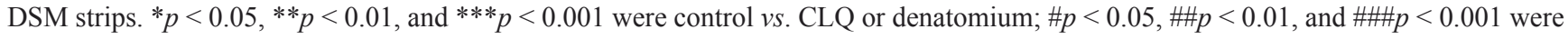
control vs. quinine, respectively. 
spontaneous phasic contractions. We found that CLQ $(100 \mu \mathrm{M})$ completely inhibited these spontaneous phasic contractions (Figure 2G). Taken together, these results suggested that TAS2R activation relaxes human DSM.

\section{Expression profile of Tas2rs in mouse DSM}

We further explored the expression profile of Tas $2 r s$ in mouse DSM with RT-qPCR. Of 35 mouse Tas $2 r$ genes, Tas2r114, Tas2r117, Tas2r130, Tas2r138, and Tas $2 r 144$ were significantly expressed. Among them, only Tas 2 r 114 was expressed at a similar level to Gapdh. Fourteen Tas $2 r$ genes were very lowly expressed, whereas 16 Tas $2 r$ genes were not detected (Figure 3).

\section{Effects of bitter tastants on carbachol-induced contractions in mouse DSM strips}

To determine the role of TAS2Rs in mouse DSM, three different bitter tastants, CLQ, denatonium, and quinine, were used. As shown in Figure 4A-4C, we found that CLQ (1 mM) mediated a two-phasic response: it first produced a slight contraction and then completely relaxed the carbachol-induced contractions. Moreover, both denatonium and quinine concentration-dependently decreased carbachol-induced contractions of mouse DSM strips (Figure 4D-4F). The vehicle had no significant effects on these contractions (Figure 4F).

\section{Chloroquine treatment attenuates bladder morphological alteration of PBOO mice}

It has been well accepted that detrusor over-activity is one of the major causes of OAB syndrome [2]. Thus, relaxation of the urinary DSM has been recognized as an effective approach to treat OAB. Our in vitro results demonstrated that TAS2Rs activation can relax both human and mouse urinary DSM (Figure 2 and 4). We therefore hypothesized that TAS2Rs activation would be effective for the treatment of OAB. To test this hypothesis, we induced a mouse model of OAB through partial obstruction of the urinary bladder outlet. The mean bodyweights of the sham, PBOO-vehicle, and PBOO-CLQ mice were not significantly different (data not shown). As shown in Figure 5A, the bladder weights of PBOO-vehicle mice $(N=8 ; 0.031 \pm 0.002 \mathrm{~g})$ were significantly increased than that of sham mice $(N=8 ; 0.022 \pm 0.002 \mathrm{~g})$; CLQ treatment markedly suppressed this increase (PBOO-CLQ mice: $N=8 ; 0.026 \pm 0.001 \mathrm{~g})$. Moreover, hematoxylineosin (HE) staining indicated that the bladder muscle thicknesses of PBOO-vehicle mice $(N=5 ; 0.40 \pm 0.03$ $\mathrm{mm})$ were markedly thicker than that of sham mice $(N=5$; $0.28 \pm 0.02 \mathrm{~mm}$ ); while CLQ treatment largely prevented PBOO-mediated muscle hypertrophy (PBOO-CLQ mice: $N=5 ; 0.32 \pm 0.01 \mathrm{~mm}$ ) (Figure $5 \mathrm{~B}$ ). In all groups, muscle fibers (stained red) and collagen fibers (stained blue) can be clearly observed in the bladder wall (Figure 5C). Consistent with HE results, masson's trichrome staining also indicated that the bladder walls were thicker in PBOO-vehicle and PBOO-CLQ mice in comparison with sham mice. Additionally, there was a transmural
A

SHAM PBOO-Vehicle PBOO-CLQ
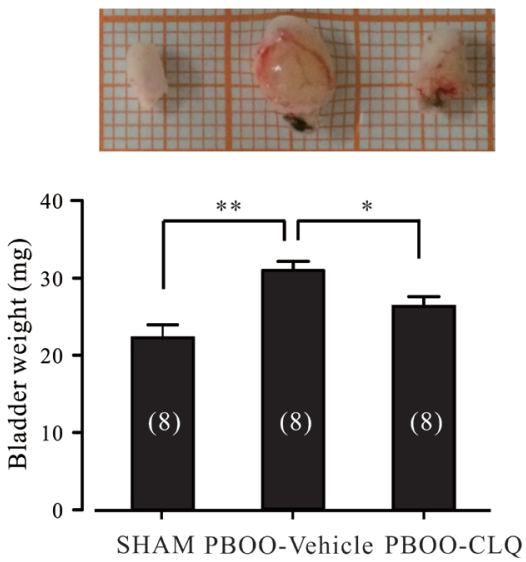

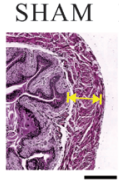

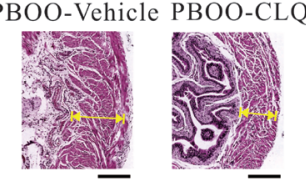

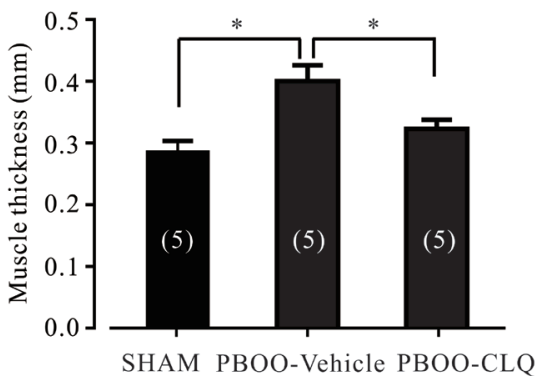

C
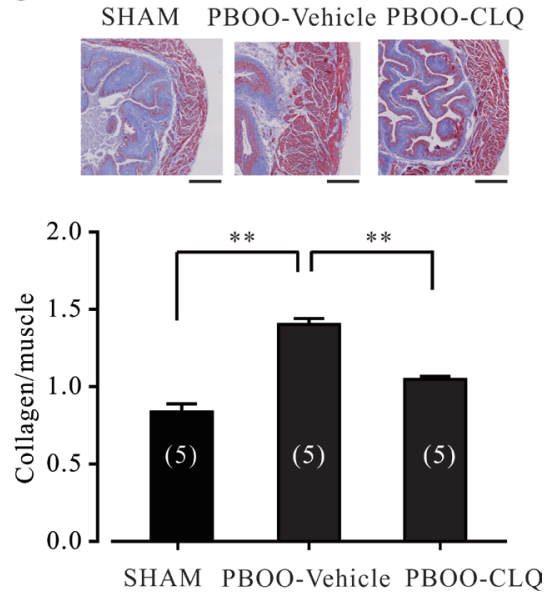

Figure 5: Chloroquine treatment significantly attenuates the bladder morphological changes of PBOO mice. A. Bladder weights of the sham $(N=8)$, PBOO-Vehicle $(N=8)$, and PBOO-CLQ $(N=8)$ mice are shown. After anesthesia, the whole bladder was removed and imaged. The fat and connective tissues were cleaned under cold PBS. Then, the bladder was cut from the neck to the fundus along one side. After being quickly dried by drinking paper, the bladder was weighed. B. The representative HE stains of bladder specimens from the sham, PBOO-Vehicle, and PBOO-CLQ mice are shown. Summary data showing the average muscle thickness of bladders from the sham $(N=5)$, PBOO-Vehicle $(N=5)$, and PBOO-CLQ $(N=5)$ mice. C. The representative Masson's trichrome staining of bladder from the sham, PBOO-Vehicle, and PBOO-CLQ mice were shown. Summary data showing the mean ratio of collagen to muscle from the sham $(N=5)$, PBOO-Vehicle $(N=5)$, and PBOO-CLQ $(N=5)$ mice. Scale bars $=250 \mu \mathrm{m} .{ }^{*} p<0.05$ and $* * p<0.01$ as indicated. 
increase in the amount of collagen in both $\mathrm{PBOO}$-vehicle and PBOO-CLQ mice. The collagen/muscle ratio in the muscle layer of bladder wall was significantly increased in PBOO-vehicle mice $(N=5 ; 1.4 \pm 0.04)$ compared to sham mice $(N=5 ; 0.84 \pm 0.05)$; this increase was markedly suppressed by CLQ treatment (PBOO-CLQ mice: $N=5$; $1.05 \pm 0.05)$.

\section{Chloroquine treatment improves bladder function of PBOO mice}

We also explored the bladder function of $\mathrm{PBOO}$ mice after CLQ treatment. As shown in Figure 6A, compared to sham mice, $\mathrm{PBOO}-$ Vehicle mice exhibited aberrant urodynamic manifestations; while PBOOCLQ mice had normal urodynamic features. In detail, maximum micturition pressure of $\mathrm{PBOO}-$ Vehicle mice was significantly higher than that of sham mice; CLQ

A

SHAM

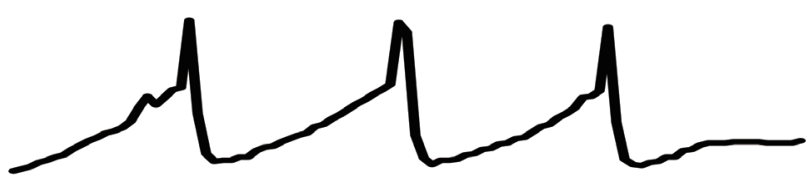

PBOO-

Vehicle
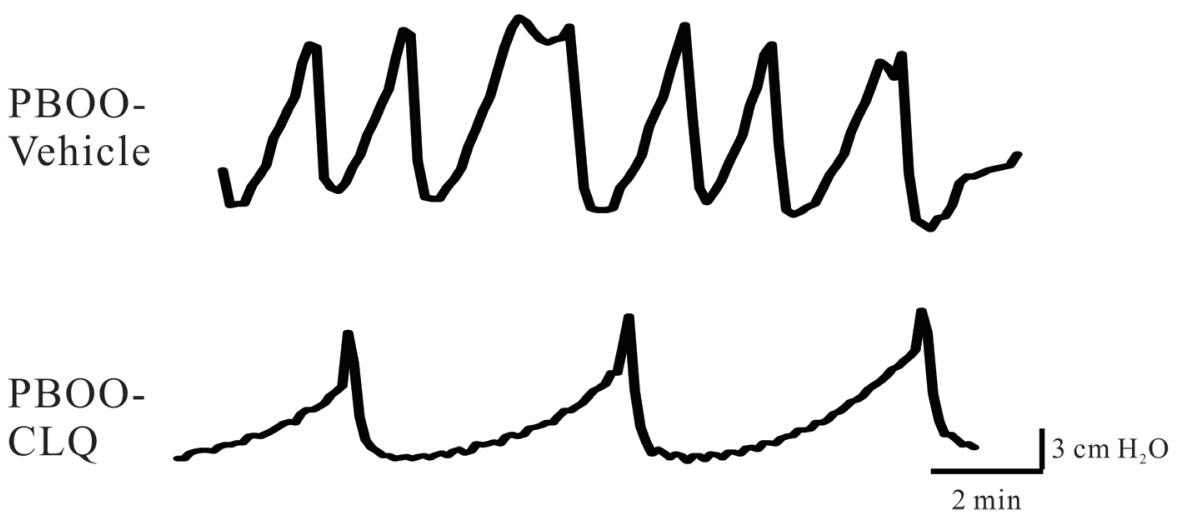

B
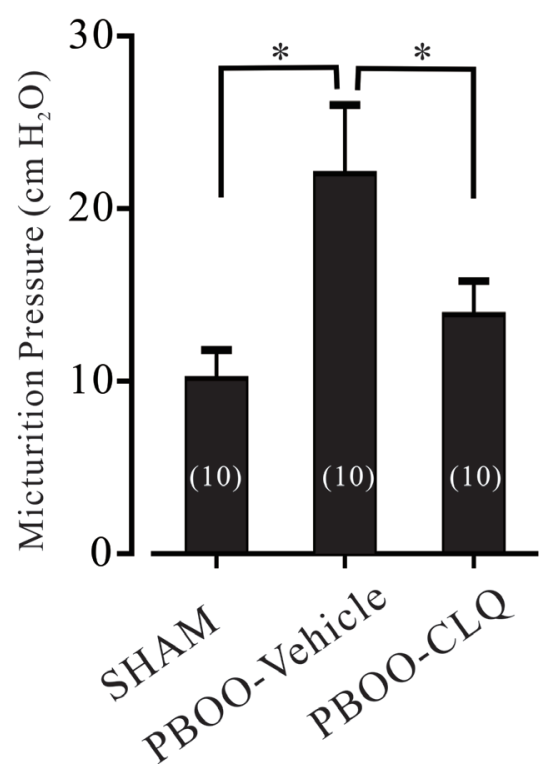

C
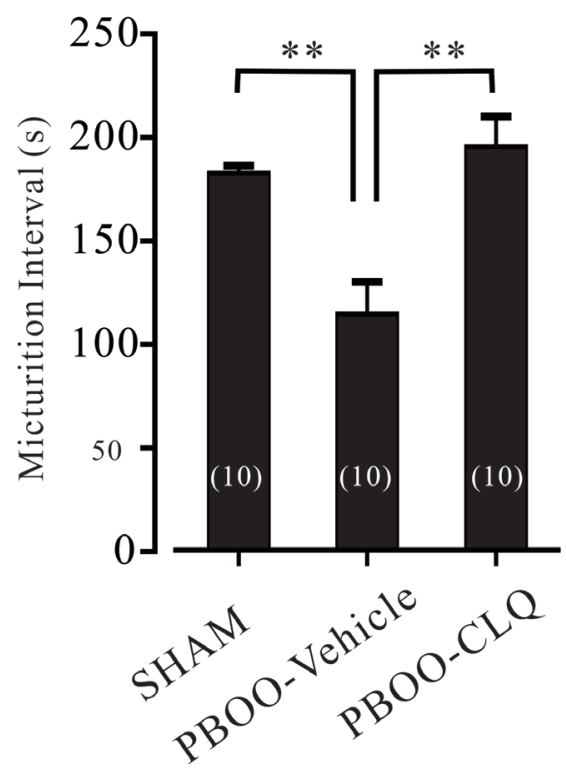

D

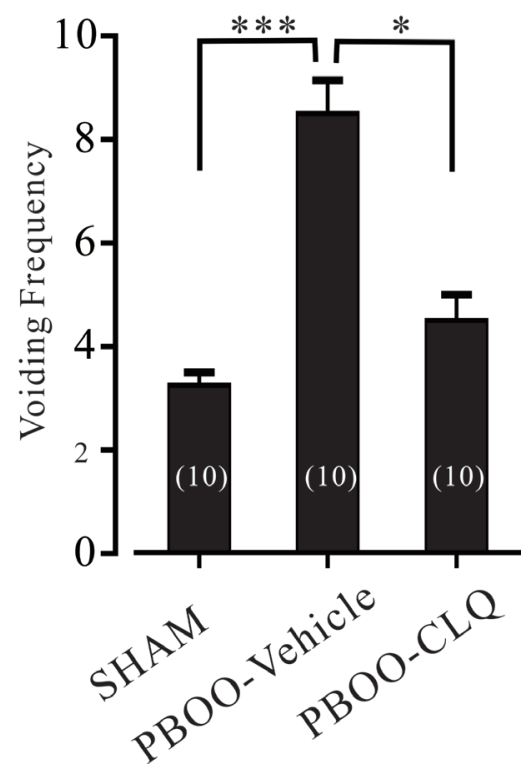

Figure 6: Chloroquine treatment improves the bladder function of PBOO mice. A. The representative traces of the cystometrogram recorded in the sham, PBOO-Vehicle, and PBOO-CLQ mice. B.-D. Summary data of micturition pressures, micturition intervals, and voiding frequency of the sham $(N=10)$, PBOO-Vehicle $(N=10)$, and PBOO-CLQ $(N=10)$ mice are shown. Data are mean \pm SEM. ${ }^{*} p<0.05, * * p<0.01$, and $* * * p<0.001$ as indicated. 
treatment suppressed this increase (Figure 6B). PBOO significantly shortened the micturition interval; however, these values were significantly prolonged and increased by CLQ treatment (Figure 6C). The micturition frequency of PBOO-Vehicle mice was largely increased compared to sham mice; this value was markedly decreased by CLQ treatment (Figure 6D).

\section{DISCUSSION}

In this study, we demonstrated for the first time that TAS2Rs exist in human and mouse DSM based on both molecular and pharmacological studies. With RTqPCR, we determined the expression profile of TAS $2 R s$ in human and mouse DSM (Figure 1 and 3). We showed that $T A S 2 R 7$ and TAS2R8 were the main subtypes expressed in human DSM (Figure 1). The murine homolog of TAS2R7, Tas2r130, was significantly detected in mouse DSM (Figure 3). Likewise, Tas2r144 was the major subtype expressed in mouse DSM (Figure 3). Its human homolog, TAS2R40, was also observed in human DSM (Figure 1). However, a large number of $T A S 2 R$ subtypes expressed in human DSM were not detected in mouse DSM. It is perhaps due to the fact that most of them are human specific TAS2Rs including TAS2R5, TAS2R8, $T A S 2 R 9$, TAS2R30, TAS2R31, and TAS2R45. With a classical pharmacological method, we showed that TAS2Rs activation induces a strong relaxation of both human and mouse DSM strips. Of interest, a transient contraction before the relaxation was observed in mouse DSM strips (Figure 4). However, this phenomenon did not occurred in human DSM. These results suggested that TAS2Rs and their downstream signaling pathways might be varied among species. Like CLQ, the other two bitter tastants, quinine and denatonium, largely relaxed the carbachol-induced contractions of mouse DSM strips in a concentration dependent manner (Figure 4D-4F), confirming the existence of TAS2Rs in mouse DSM. We also found that CLQ had no obvious effects on the base tone but suppressed stimulus-induced contractions of DSM, implying that the underlying signaling pathways might be different between the resting and pre-contracted conditions. It has been shown that TAS2Rs activation mediates two opposing signaling pathways in the airway smooth muscle [14].

In the airway epithelium, TAS2Rs expressed on the ciliated epithelial cells [26] and solitary chemosensory cells $[27,28]$, where they promote ciliary beat frequency and sense chemical irritation, respectively. Here, we did not focus the role of TAS2Rs in the urothelium of urinary bladder. It is hard to obtain the human bladder tissues with normal urothelium in our experimental conditions. In most cases, only the DSM sections were delivered to the lab from the hospital. In order to keep consistent with findings in the human urinary DSM, we only investigated the role of TAS2Rs in mouse DSM. However, it will be very interesting to test the role of TAS2Rs in the urothelium of urinary bladder.

Another primary finding of this study is that CLQ treatment suppresses OAB symptoms. We showed that once daily $30 \mathrm{mg} / \mathrm{kg}$ of CLQ for 6 weeks can attenuate PBOO-induced DSM hypertrophy and collagen deposition (Figure 5) and improve bladder functions of PBOO mice (Figure 6). The dosage of CLQ used in this study was based on previous observations. Sexton et al. showed that 25 and $50 \mathrm{mg} / \mathrm{kg}$ of CLQ are effective for the treatment of human malaria [29]. In a murine malaria model, a single dose of $50 \mathrm{mg} / \mathrm{kg}$ of CLQ can protect mice from experimental malaria [30]. It has been reported that once daily $30 \mathrm{mg} / \mathrm{kg}$ of CLQ has no significant effects on the behavior and appearance of the mice [31]. Moore et al. found that the maximum plasma concentration of CLQ can reach to $1708 \mu \mathrm{g} /$ liter (about $6 \mu \mathrm{M}$ ) after the treatment of a single dose of CLQ $(50 \mathrm{mg} / \mathrm{kg})$ in the mice [32]. CLQ concentration can be accumulated more than 10 times after the successive treatment of CLQ for 20 days in human [33]. As the pharmacokinetics of CLQ is similar between human and mouse [32], we calculated that the plasma concentration of CLQ should be maintained from 10 to $100 \mu \mathrm{M}$ during CLQ treatment. After PBOO surgery, the bladder underwent structural and functional remodeling to adapt the excessive mechanical stress [34]. One of the major functional alterations caused by PBOO is detrusor over-activity, which is characterized by increased responses to stimuli and micturition dysfunction. The super-sensitivity of the detrusor to acetylcholine (Ach) has been reported in the animal model [35] as well as in OAB patients [36]. Thus, CLQ treatment suppresses detrusor over-activity and leads to the improvement of the bladder function of PBOO mice. Recently, Long et al. showed that CLQ can prevent the hypertrophy of right ventricular through the inhibition of autophagy pathways [37], raising the possibility that there are the other mechanisms responsible for the effects of CLQ treatment.

In this study, the OAB model was generated with female mice because of the ease of manipulation. It is known that animal models always have several limitations, including the fact the prevalence of bladder obstruction is higher in males than in females. Besides the obstruction of bladder outlet, there are numerous causes of OAB in human. Thus, the effects of CLQ needs to be further investigated with the other OAB models.

There is an unmet need for additional therapeutic options in the treatment of OAB. Here, we provide evidence of the existence of TAS2Rs in both human and mouse urinary DSM and further demonstrate that CLQ can improve OAB symptoms of PBOO mice. Indeed, many known synthetic agents and thousands of natural bitter tastants and their metabolites can activate TAS2Rs and have favorable therapeutic profiles. Therefore, these findings open a new approach to develop drugs for $\mathrm{OAB}$ in the future. 
Table 1: Sequence information of RT-qPCR primers

\begin{tabular}{|c|c|c|c|c|}
\hline $\begin{array}{l}\text { Gene } \\
\text { symbol }\end{array}$ & Accession number & Forward sequence & Reverse sequence & Size (bp) \\
\hline TAS2R1 & NM_019599.2 & tgccattgcttatcttccttttt & ggtgtgcctccccagaga & 62 \\
\hline TAS2R3 & NM_016943.2 & caaaaaccaagatggctaagatga & tgagtggccagcaggataaaa & 65 \\
\hline TAS2R4 & NM_016944.1 & tttcctgaacttgtgactacgagaa & taaagacaagatgccetcactgata & 66 \\
\hline TAS2R5 & NM_018980.2 & cagcattcggtatccctttga & tcctgaattgagctgaaatgca & 61 \\
\hline TAS2R7 & NM_023919.2 & aacgetgetcccettttgt & cgcagggagaggatcaagag & 60 \\
\hline TAS2R8 & NM_023918.1 & aaaactctatgctaccggcagtaga & agtcatagttttaatggctctcacatg & 70 \\
\hline TAS2R9 & NM_023917.2 & tgcatgctacagggttcagaga & tgectttatggecetcatgt & 59 \\
\hline TAS2R10 & NM_023921.1 & catttccctttggagacacaac & atgagcttctgtgttggagtc & 76 \\
\hline TAS2R13 & \begin{tabular}{|l|} 
NM_023920.2 \\
\end{tabular} & \begin{tabular}{|l} 
aggagcagaaaaaggagaagg \\
\end{tabular} & gtgaagatactcggcaggg & 147 \\
\hline TAS2R14 & \begin{tabular}{|l|} 
NM_023922.1 \\
\end{tabular} & cctcactgetttggcaatctc & acacacaccagcttccgaatatt & 65 \\
\hline TAS2R16 & NM_016945.2 & \begin{tabular}{|l|} 
cattggttattcctttcatcctgtt \\
\end{tabular} & cttggtcagtgatgccatgaga & 65 \\
\hline TAS2R19 & NM_176888.1 & cgaaccatttcagcatgtgg & ccccaacagtatcaccagaac & 134 \\
\hline TAS2R20 & NM_176889.2 & agatggagtcttgecctgttgt & ttgtggtgagccaagattgtg & 62 \\
\hline TAS2R30 & NM_001097643.1 & \begin{tabular}{|l} 
atttcagcagctggettgcta \\
\end{tabular} & aaattggcaatcctgagcaaa & 61 \\
\hline TAS2R31 & NM_176885.2 & cagcaccaaggtccacataaaa & gtaaacggcacataacaagaggaa & 67 \\
\hline TAS2R38 & NM_176817.4 & ctctgtgccectactgattctgt & cattatcccaacacaaaccatcac & 64 \\
\hline TAS2R39 & NM_176881.2 & ccetgccagccactcaat & ccgettccaggctcttctc & 64 \\
\hline TAS2R40 & NM_176882.1 & tgccggecactcagtacaa & accgettccaggetcttctc & 62 \\
\hline TAS2R41 & NM_176883.2 & cggecgacagttcttcca & aaaaccagaaggtggetgagttc & 59 \\
\hline TAS2R42 & NM_181429.1 & actggtaaactgctctgaagg & atgtgaagcaagtcccactag & 139 \\
\hline TAS2R43 & NM_176884.2 & gcaccaaggtccacataaaagc & aagtaaatggcacataacaagaggaa & 67 \\
\hline TAS2R45 & NM_176886.1 & cctttgctgaccaaattgtcact & taataataacacccagagcaaaccaa & 68 \\
\hline TAS2R46 & NM_176887.2 & gctattgcattcagctatccttca & agcttcttgtttccccaaatca & 62 \\
\hline TAS2R50 & NM_176890.2 & \begin{tabular}{|l} 
gttgtcatggttagcaaggc \\
\end{tabular} & gagttgagagtttcaggtcttttac & 148 \\
\hline TAS2R60 & NM_177437.1 & caatgeccactgctgtctttt & tgtgtcttcccagagatgtgatg & 63 \\
\hline hGAPDH & NM_002046.5 & \begin{tabular}{|l} 
gccacatcgctcagacacc \\
\end{tabular} & cccaatacgaccaaatccgt & 64 \\
\hline Tas2r102 & NM_199153.2 & ggaagcttggtgttcttgcttgg & agatcagctcggtccacattgc & 127 \\
\hline Tas2r103 & NM_053211.1 & attagcactgggtttacactcacc & ccacagggagaagatgagcagaag & 75 \\
\hline Tas2r104 & NM_207011.1 & agcttcctttccgetagctgtg & \begin{tabular}{|l} 
tggatcagccaggatgtgttgc \\
\end{tabular} & 75 \\
\hline Tas2r105 & NM_020501.1 & \begin{tabular}{|l} 
ttcettctcatcggcttagca \\
\end{tabular} & gtcaggtgattcacagtcatcc & 152 \\
\hline Tas2r106 & NM_207016.1 & tgcctctgatgeccacattatag & ggctggtggcaaaccatatacttg & 80 \\
\hline Tas2r107 & NM_199154.1 & tccetgcggtcactcaatcatc & cagtgccttcaaagaggcttgc & 70 \\
\hline Tas2r108 & NM_020502.1 & agtgtttctcctgttgaaacggac & tggtgagggctgaaatcagaag & 83 \\
\hline Tas2r109 & NM_207017.1 & gtcaaattcaggtgttaggaagtcac & cacagggagaagatgagcagga & 94 \\
\hline Tas2r110 & NM_199155.2 & tggatagtgaataaccatttcagcg & ctccactttaggtaaagaaacaaagagt & 110 \\
\hline Tas2r113 & NM_207018.1 & tccgcactgctctggcaattag & tgaacagacacccaccaatctagg & 73 \\
\hline Tas2r114 & NM_207019.1 & tgctgagcacaatggaaggtgtc & tgttccetacaatgcccagcac & 72 \\
\hline Tas2r115 & NM_207020.1 & ctttggtgtatccttgatagctttcc & gtactgcatcttccttacatgtttcat & 73 \\
\hline Tas2r116 & NM_053212.1 & cttttgctgtgtcactggtca & tctgatgtgggecttagtgct & 119 \\
\hline Tas2r117 & NM_207021.1 & cttttcgttgtattttgtgaggttgt & ctgtctcagcttcatgtctcctaca & 90 \\
\hline Tas2r118 & NM_207022.1 & aagttgcacaacggttgcagtg & tctccaccggtgacagtctttg & 68 \\
\hline Tas2r119 & NM_020503.2 & ctcaaggaacccaagactcagtg & acaggcttctgagcaggatgtc & 82 \\
\hline Tas2r120 & NM_207023.1 & atggcaaaggatgtcaagatcag & atgacctgctgggtagaagga & 182 \\
\hline Tas2r121 & NM_207024.1 & ctggtcttattggagatgattgtgtt & ggagaagattaacaggatgaaggaga & 81 \\
\hline Tas2r122 & NM_001039128.1 & tcttctctttatggagccaccttag & gtgcttctgtgcttatgtctttgg & 75 \\
\hline Tas2r123 & NM_207025.1 & cattaaagccttgcaaactgtgttc & ggaaaagtaagtatatggcatacagca & 62 \\
\hline Tas2r124 & NM_207026.1 & agtctctggcttgctacagctc & agcttcccagaagcatgtggac & 127 \\
\hline Tas2r125 & NM_207027.1 & atcttctccetgtggagacacctg & tggtgtcttcggagcetttagc & 64 \\
\hline Tas2r126 & NM_207028.1 & gcagtgtgtgggattggtcaac & tcccggagtactcaaccagatg & 62 \\
\hline
\end{tabular}




\begin{tabular}{|l|l|l|l|l|}
\hline Tas2r129 & NM_207029.1 & ttgcagatgcccacatcagagtc & tggcacagagtaggacataggtg & 60 \\
\hline Tas2r130 & NM_199156.1 & tccttcctggccctgttg & tgaatggcttgaaggatagattagag & 132 \\
\hline Tas2r131 & NM_207030.1 & atcaacatggcttgccacctg & agcacacctctcaatctccactta & 105 \\
\hline Tas2r134 & NM_199158.1 & gcctgggaagtggtaacctaca & gtgttgcttagtatcagaatggtgga & 63 \\
\hline Tas2r135 & NM_199159.1 & tcagttctgccagcaacacacc & tgaatcaccacctgccacatcc & 64 \\
\hline Tas2r136 & NM_181276.1 & tctggaggaaccaatccacctg & tgctctcacctgaaccattgcc & 133 \\
\hline Tas2r137 & NM_001025385.1 & ctggctcaaatggagagcttcta & ggtactgacacaggataagagcagtg & 76 \\
\hline Tas2r138 & NM_001001451.1 & tgctattcagctcgcctgcttc & tggcttggtagttgtggctcag & 62 \\
\hline Tas2r139 & NM_181275.1 & tgacaatgttcgtcgcaacagc & tcatgttcagggtgtgtctcctg & 66 \\
\hline Tas2r140 & NM_021562.1 & catctgaagaacatgcaacacaatg & gcagggccttaatatgggct & 73 \\
\hline Tas2r143 & NM_001001452.1 & ttccaggctgctggttgtatc & agttccggtggctgaaatgac & 69 \\
\hline Tas2r144 & NM_001001453.1 & tggtttgctgcttggctcaatg & tcagaaggaacagagggtgagc & 73 \\
\hline mGapdh & NM_008084.2 & aaggtcggtgtgaacggatttg & tcctggaagatggtgatgggct & 224 \\
\hline
\end{tabular}

\section{MATERIALS AND METHODS}

This study was reviewed and approved by the local Institutional Review Board of Peking University First Hospital and the Institute of Biophysics Committee. For experiments involving human subjects, the research was conducted according to the principles expressed in the Declaration of Helsinki. Animal protocols were performed according to the Guide for the Care and Use of Laboratory Animals published by the US National Institutes of Health (NIH Publication No. 85-23, revised 1996).

\section{Obtainment of human urinary bladder tissues}

Human urinary bladder tissues were obtained from 26 patients with bladder cancer (18 men and 8 women, mean age: $66 \pm 7 \mathrm{yr}$ ) who had undergone radical cystectomy in Peking University First Hospital. The patients with urinary retention, obvious lower urinary tract symptoms, or with medical conditions that could affect bladder function were excluded. In addition, the patients whose DSM layers were severely affected by cancer were also excluded. Bladder tissues were removed and confirmed to be cancer-free by an experienced urological pathologist. After the cleaning of fat tissue and peeling of bladder serosa and mucosa, human DSM samples were collected.

Adult C57BL/6J mice (8-week old, 18-22 g) were purchased from Vital River Laboratories (Beijing, China), housed with free access to food and water and maintained on a 12 hour light/dark cycle. Mice were anesthetized by $5 \%$ chloral hydrate and the whole bladder was removed, placed into cold Tyrode solution composed of (mM): $137 \mathrm{NaCl}, 5.4 \mathrm{KCl}, 1.8 \mathrm{CaCl}_{2}, 1.0 \mathrm{MgCl}_{2}, 10$ glucose, 10 HEPES, ( $\mathrm{pH}$ 7.4). After the cleaning of the fat tissues, the bladder was cut into two longitudinal pieces by using a fine dissecting scissors along the axis from the neck to the fundus. Then, the urothelium was carefully removed. The DSM tissues were collected for organ baths or RT-qPCR experiments.

\section{RT-qPCR}

RNA and cDNA were prepared as previously reported [38]. In brief, total RNA was prepared from bladder DSM using the Trizol RNA purification system (Invitrogen, Carlsbad, CA, USA). The cDNA was generated from mRNA $(2 \mu \mathrm{g})$ using the M-MLV reverse transcriptase (Promega Corp., Madison, WI, USA). RT-qPCR was performed on a Corbett RotorGene 6600 QPCR system machine (Corbett Life Science) using TransScript ${ }^{\mathrm{TM}}$ Green RT-qPCR SuperMix (TRANSGENE BIOTECH, Beijing, China) according to the manufacturer's instructions. GAPDH was used as a reference gene. Detailed information regarding the primer pairs used in this study was shown in Table 1. All the PCR products were run on the gel or sequenced to test the specificity of each pair of primer. The $2^{-\mathrm{ACt}}$ method was used to analyze the relative expression levels of TAS2Rs.

\section{Isometric DSM tension recordings}

Organ bath experiments were performed as previously reported $[39,40]$. In brief, the mucosa-free DSM strips from human or mouse were dissected into strips 5-8 $\mathrm{mm}$ long and 2-3 $\mathrm{mm}$ wide. Strips were tied up and mounted in the standard organ bath chambers (BL-420F acquisition system, Chengdu TME Technology Co, Ltd, Sichuan, China) filled with KREBs solution maintained at $37^{\circ} \mathrm{C}$ and aerated with $95 \% \mathrm{O}_{2}$ and $5 \% \mathrm{CO}_{2}$. DSM strips were passively stretched and equilibrated for 1.5 hour. After equilibration, $\mathrm{KCl}(80 \mathrm{mM})$ or carbachol $(10 \mu \mathrm{M})$ were applied to pre-contract the DSM strips. CLQ, denatonium, and quinine were prepared as $1,000 \mathrm{x}$ in MilliQ water just before use. The equal volume of MilliQ water was used as positive controls. When the contraction responses were stable, cumulative CLQ (100 $\mathrm{nM}$ to $3 \mathrm{mM}$ ) or the positive controls was added to the chambers. To analyze the effects of CLQ, denatonium, and quinine, the stable contractions induced by $\mathrm{KCl}$ $(80 \mathrm{mM})$ or carbachol $(10 \mu \mathrm{M})$ was taken as $100 \%$ and 
the responses to subsequent bitter tastants or control applications were normalized. For EFS experiments, DSM contractions were generated by applying increasing EFS frequencies $(0.5,2,3.5,5,7.5,10,12.5,15,20,30,40$, $50 \mathrm{~Hz}$ ). EFS pulses were generated using the BL-420F acquisition system (Chengdu TME Technology Co, Ltd) and had the following parameters: pulse amplitude was 20 $\mathrm{V}$, pulse width was $0.75 \mathrm{~ms}$, stimulus duration was $3 \mathrm{~s}$, and polarity was reversed for alternating pulses according to a previous study [25]. Five minutes after the addition of 100 $\mu \mathrm{M}$ CLQ, a second EFS stimulation with same frequencies was applied. To analyze the effects of CLQ on the EFS generated contractions, the contraction amplitude at 0.5 $\mathrm{Hz}$ of the first EFS stimulation was taken as one and the other contraction amplitudes were normalized to it and shown as fold changes.

\section{Partial bladder outlet obstruction}

The OAB mouse model was induced with female C57BL/6J mice (8-week old, 18-22g) as previously described [41]. In brief, mice were anesthetized with 5\% chloral hydrate, then abdomen was opened by a lower midline incision. The bladder and urethra were carefully separated from the surrounding tissues. After placing a $0.5-$ $\mathrm{mm}$ metal rod alongside the proximal urethra, a 4-0 nylon ligature was tied both the rod and the urethra to make an infravesical obstruction. The rod was subsequently removed, before closing the abdomen. Sham-operated animals served as controls. Two weeks after surgery, the PBOO mice were divided into two subgroups as follows: one group received once $30 \mathrm{mg} / \mathrm{kg}$ of CLQ for 6 weeks via oral gavage (as PBOO-CLQ mice), and the other group received normal saline (as PBOO-Vehicle mice). The sham-operated mice received normal saline only.

\section{Histological examination}

The urinary bladders were fixed with 4\% paraformaldehyde, embedded in paraffin and sectioned ( 5 $\mu \mathrm{m})$ onto glass slides. HE staining and Masson's trichrome staining were carried out by using standard protocols. Images were acquired on a Leica SCN400 Scanner microscope (Leica). To determine the bladder muscle thickness, images of HE staining were analyzed by Image J. Nine non-overlapping fields per mouse bladder were measured and the mean of the bladder muscle thickness was calculated. To measure the ratio of collagen/muscle in the bladder muscle layer, images of masson's trichrome staining were analyzed by using Image Pro Plus software. Through color recognition, this system automatically measures the area of each color. Nine fields per mouse bladder were manually chose and analyzed. This analysis was carried out by a single person, who was completely blinded to the experimental data and all other variables.

\section{Cystometry}

As reported previously [42], the mice underwent a surgical procedure for catheter (PE-10) insertion. The mice were anesthetized with 5\% chloral hydrate. The abdomen was opened and a PE-10 catheter was inserted into the bladder and fixed with a surgeon's knot. After closure the muscle, the catheter was tunneled subcutaneously and an orifice made at the back of the animal. Three days after surgery, conscious mice were placed in cages without any restraints. The PE-10 tube was connected to a pressure transducer (LABORIE, Canada) and an infusion pump (B. Braun Medical, Inc., Germany) through a 3-way tap. Saline solution $\left(37^{\circ} \mathrm{C}\right)$ was infused into the bladder at a rate of $1.2 \mathrm{ml} / \mathrm{h}$. Urodynamic values were recorded continuously using data acquisition software (LABORIE, Canada). The following cystometric parameters were recorded and analyzed in this study: maximal micturition pressure at the start of micturition, micturition frequency, and inter-micturition interval.

\section{Statistical analysis}

Data were represented as mean \pm SEM of $n$ strips in organ bath experiments and $\mathrm{N}$ mice in histologicalexamination/cystometry experiments. Significant differences were determined by Student's $t$-test. Only results with values of $p<0.05$ were considered significant.

\section{ACKNOWLEDGMENTS}

We thank the staff in the Department of Urology at Peking University First Hospital for the help of collecting human bladder tissues. We thank Xudong Zhao and Su Liu for technical supports and the animal core facility for efficient animal care.

\section{Authors' contributions}

GJ, KZ, and JJ conceived and designed the experiments. KZ, ZY, XZ, EN, and YW performed the experiments. KZ and ZY analyzed the data. YM, QL, SW, and LM contributed to reagents/materials/analysis tools. $\mathrm{KZ}$ and GJ wrote the paper. All authors gave final approval for publication.

\section{CONFLICTS OF INTERESTS}

The authors declare no financial conflicts of interest.

\section{FUNDING}

This work was supported by grants from the National Natural Science Foundation of China (31300956 
to ZK) and the National Basic Research Program of China (2011CB809104 to GJ).

\section{REFERENCES}

1. Abrams P, Kelleher CJ, Kerr LA and Rogers RG. Overactive bladder significantly affects quality of life. Am J Manag Care. 2000; 6:S580-S590.

2. Wein AJ and Rackley RR. Overactive bladder: a better understanding of pathophysiology, diagnosis and management. J Urol. 2006; 175:S5-10.

3. Irwin DE, Milsom I, Hunskaar S, Reilly K, Kopp Z, Herschorn S, Coyne K, Kelleher C, Hampel C, Artibani $\mathrm{W}$ and Abrams P. Population-based survey of urinary incontinence, overactive bladder, and other lower urinary tract symptoms in five countries: results of the EPIC study. Eur Urol. 2006; 50:1306-1314.

4. Stewart WF, Van Rooyen JB, Cundiff GW, Abrams P, Herzog AR, Corey R, Hunt TL and Wein AJ. Prevalence and burden of overactive bladder in the United States. World J Urol. 2003; 20:327-336.

5. Wen JG, Li JS, Wang ZM, Huang CX, Shang XP, Su ZQ, Lu YT, Suo ZH, Wang Y, Qin GJ, Zhang WX and Heesakkers JP. The prevalence and risk factors of OAB in middle-aged and old people in China. Neurourol Urodyn. 2014; 33:387-391.

6. Athanasopoulos A, Chapple C, Fowler C, Gratzke C, Kaplan $\mathrm{S}$, Stief $\mathrm{C}$ and Tubaro A. The role of antimuscarinics in the management of men with symptoms of overactive bladder associated with concomitant bladder outlet obstruction: an update. Eur Urol. 2011; 60:94-105.

7. Buser N, Ivic S, Kessler TM, Kessels AGH and Bachmann LM. Efficacy and Adverse Events of Antimuscarinics for Treating Overactive Bladder: Network Meta-analyses. Eur Urol. 2012; 62:1040-1060.

8. Irwin DE, Kopp ZS, Agatep B, Milsom I and Abrams P. Worldwide prevalence estimates of lower urinary tract symptoms, overactive bladder, urinary incontinence and bladder outlet obstruction. BJU Int. 2011; 108:1132-1138.

9. Behrens $\mathrm{M}$ and Meyerhof W. Bitter taste receptors and human bitter taste perception. Cell Mol Life Sci. 2006; 63:1501-1509.

10. Overington JP, Al-Lazikani B and Hopkins AL. How many drug targets are there? Nat Rev Drug Discov. 2006; 5:993996.

11. Insel PA, Snead A, Murray F, Zhang L, Yokouchi H, Katakia T, Kwon O, Dimucci D and Wilderman A. GPCR expression in tissues and cells: are the optimal receptors being used as drug targets? Br J Pharmacol. 2012; 165:1613-1616.

12. Deshpande DA, Wang WC, McIlmoyle EL, Robinett KS, Schillinger RM, An SS, Sham JS and Liggett SB. Bitter taste receptors on airway smooth muscle bronchodilate by localized calcium signaling and reverse obstruction. Nat
Med. 2010; 16:1299-1304.

13. Zhang $\mathrm{CH}$, Chen C, Lifshitz LM, Fogarty KE, Zhu MS and ZhuGe R. Activation of BK channels may not be required for bitter tastant-induced bronchodilation. Nat Med. 2012; 18:648-650.

14. Zhang CH, Lifshitz LM, Uy KF, Ikebe M, Fogarty KE and ZhuGe R. The cellular and molecular basis of bitter tastantinduced bronchodilation. PLoS Biol. 2013; 11:e1001501.

15. Zhang T, Luo XJ, Sai WB, Yu MF, Li WE, Ma YF, Chen W, Zhai K, Qin G, Guo D, Zheng YM, Wang YX, Shen JH, et al. Non-selective cation channels mediate chloroquineinduced relaxation in precontracted mouse airway smooth muscle. PLoS One. 2014; 9:e101578.

16. Foster SR, Blank K, See Hoe LE, Behrens M, Meyerhof W, Peart JN and Thomas WG. Bitter taste receptor agonists elicit G-protein-dependent negative inotropy in the murine heart. FASEB J. 2014; 28:4497-4508.

17. Clark AA, Dotson CD, Elson AE, Voigt A, Boehm U, Meyerhof W, Steinle NI and Munger SD. TAS2R bitter taste receptors regulate thyroid function. FASEB J. 2015; 29:164-172.

18. Avau B, Rotondo A, Thijs T, Andrews CN, Janssen P, Tack J and Depoortere I. Targeting extra-oral bitter taste receptors modulates gastrointestinal motility with effects on satiation. Sci Rep. 2015; 5:15985.

19. Meyerhof W, Batram C, Kuhn C, Brockhoff A, Chudoba E, Bufe B, Appendino G and Behrens M. The molecular receptive ranges of human TAS2R bitter taste receptors. Chem Senses. 2010; 35:157-170.

20. Grassin-Delyle S, Abrial C, Fayad-Kobeissi S, Brollo M, Faisy C, Alvarez JC, Naline E and Devillier P. The expression and relaxant effect of bitter taste receptors in human bronchi. Resp Res. 2013; 14.

21. Bassoli A, Borgonovo G, Caremoli F and Mancuso G. The taste of D- and L-amino acids: In vitro binding assays with cloned human bitter (TAS2Rs) and sweet (TAS1R2/ TAS1R3) receptors. Food Chem. 2014; 150:27-33.

22. Mills IW, Greenland JE, McMurray G, McCoy R, Ho KM, Noble JG and Brading AF. Studies of the pathophysiology of idiopathic detrusor instability: the physiological properties of the detrusor smooth muscle and its pattern of innervation. J Urol. 2000; 163:646-651.

23. Hristov KL, Parajuli SP, Soder RP, Cheng Q, Rovner ES and Petkov GV. Suppression of human detrusor smooth muscle excitability and contractility via pharmacological activation of large conductance $\mathrm{Ca} 2+$-activated $\mathrm{K}+$ channels. Am J Physiol Cell Physiol. 2012; 302:C16321641.

24. Yamanishi T, Kaga K, Fuse M, Shibata C, Kamai T and Uchiyama T. The role of muscarinic receptor subtypes on carbachol-induced contraction of normal human detrusor and overactive detrusor associated with benign prostatic hyperplasia. J Pharmacol Sci. 2015; 128:65-70.

25. Afeli SA, Rovner ES and Petkov GV. SK but not IK 
channels regulate human detrusor smooth muscle spontaneous and nerve-evoked contractions. Am J Physiol Renal Physiol. 2012; 303:F559-568.

26. Shah AS, Ben-Shahar Y, Moninger TO, Kline JN and Welsh MJ. Motile cilia of human airway epithelia are chemosensory. Science. 2009; 325:1131-1134.

27. Tizzano M, Gulbransen BD, Vandenbeuch A, Clapp TR, Herman JP, Sibhatu HM, Churchill ME, Silver WL, Kinnamon SC and Finger TE. Nasal chemosensory cells use bitter taste signaling to detect irritants and bacterial signals. Proc Natl Acad Sci U S A. 2010; 107:3210-3215.

28. Tizzano M, Cristofoletti M, Sbarbati A and Finger TE. Expression of taste receptors in solitary chemosensory cells of rodent airways. BMC Pulm Med. 2011; 11:3.

29. Sexton JD, Deloron P, Bugilimfura L, Ntilivamunda A and Neill M. Parasitologic and clinical efficacy of 25 and $50 \mathrm{mg} /$ $\mathrm{kg}$ of chloroquine for treatment of Plasmodium falciparum malaria in Rwandan children. Am J Trop Med Hyg. 1988; 38:237-243.

30. Zhu X, Pan Y, Li Y, Jiang Y, Shang H, Gowda DC, Cui L and Cao Y. Targeting Toll-like receptors by chloroquine protects mice from experimental cerebral malaria. Int Immunopharmacol. 2012; 13:392-397.

31. Ramadan A, Wheatcroft MD, Quan A, Singh KK, Lovren F, Dhingra N, Teoh H, Al-Omran M, Leong-Poi H and Verma $\mathrm{S}$. Effects of long-term chloroquine administration on the natural history of aortic aneurysms in mice. Can J Physiol Pharmacol. 2015; 93:641-648.

32. Moore BR, Page-Sharp M, Stoney JR, Ilett KF, Jago JD and Batty KT. Pharmacokinetics, pharmacodynamics, and allometric scaling of chloroquine in a murine malaria model. Antimicrob Agents Chemother. 2011; 55:38993907.

33. Wetsteyn JC, De Vries PJ, Oosterhuis B and Van Boxtel CJ. The pharmacokinetics of three multiple dose regimens of chloroquine: implications for malaria chemoprophylaxis. Br J Clin Pharmacol. 1995; 39:696-699.

34. Mirone V, Imbimbo C, Longo N and Fusco F. The detrusor muscle: an innocent victim of bladder outlet obstruction. Eur Urol. 2007; 51:57-66.
35. Sibley GN. The physiological response of the detrusor muscle to experimental bladder outflow obstruction in the pig. British journal of urology. 1987; 60:332-336.

36. Harrison SC, Hunnam GR, Farman P, Ferguson DR and Doyle PT. Bladder instability and denervation in patients with bladder outflow obstruction. Br J Urol. 1987; 60:519522.

37. Long L, Yang X, Southwood M, Lu J, Marciniak SJ, Dunmore BJ and Morrell NW. Chloroquine prevents progression of experimental pulmonary hypertension via inhibition of autophagy and lysosomal bone morphogenetic protein type II receptor degradation. Circ Res. 2013; 112:1159-1170.

38. Zhai K, Hubert F, Nicolas V, Ji G, Fischmeister R and Leblais V. beta-Adrenergic cAMP signals are predominantly regulated by phosphodiesterase type 4 in cultured adult rat aortic smooth muscle cells. PLoS One. 2012; 7:e47826.

39. Zhai K, Chang Y, Wei B, Liu Q, Leblais V, Fischmeister $\mathrm{R}$ and Ji G. Phosphodiesterase types 3 and 4 regulate the phasic contraction of neonatal rat bladder smooth myocytes via distinct mechanisms. Cell Signal. 2014; 26:1001-1010.

40. Hubert F, Belacel-Ouari M, Manoury B, Zhai K, DomergueDupont V, Mateo P, Joubert F, Fischmeister R and Leblais V. Alteration of vascular reactivity in heart failure: Role of phosphodiesterases type 3 and 4. Br J Pharmacol. 2014;171:5361-5375.

41. Pandita RK, Fujiwara M, Alm P and Andersson KE. Cystometric evaluation of bladder function in nonanesthetized mice with and without bladder outlet obstruction. J Urol. 2000; 164:1385-1389.

42. Uvin P, Everaerts W, Pinto S, Alpizar YA, Boudes M, Gevaert T, Voets T, Nilius B, Talavera K and De Ridder D. The Use of Cystometry in Small Rodents: A Study of Bladder Chemosensation. J Vis Exp. 2012; (66): e3869. 